\title{
PENGARUH MODEL PEMBELAJARAN CIRCUIT LEARNING BERBANTUAN MEDIA FLIPCHART TERHADAP KOMPETENSI PENGETAHUAN IPS SISWA KELAS V
}

\author{
Rafflesines Yuanisa Romaliyana1, Made Putra², I Wayan sujana ${ }^{3}$ \\ 1 Jurusan Pendidikan Dasar, Universitas Pendidikan Ganesha, Singaraja, Indonesia \\ 2 Jurusan Pendidikan Dasar, Universitas Pendidikan Ganesha, Singaraja, Indonesia \\ 3 Jurusan Pendidikan Dasar, Universitas Pendidikan Ganesha, Singaraja, Indonesia
}

\begin{abstract}
Abstrak
Penelitian ini bertujuan untuk mengetahui pengaruh model pembelajaran circuit learning berbantuan media flipchart terhadap kompetensi pengetahuan IPS siswa kelas V SDN Gugus I Kecamatan Kuta tahun ajaran 2018/2019. Penelitian ini merupakan penelitian eksperimen semu dengan rancangan nonequivalent Post Test Only control group design. Populasi dalam penelitian ini adalah seluruh siswa kelas V SDN Gugus I Kecamatan Kuta yang berjumlah 343 siswa. Sampel penelitian ditentukan dengan cara random sampling dan diperoleh kelas V SD No. 3 Kuta sebagai kelompok eksperimen dan kelas Va SD No. 4 Kuta sebagai kelompok kontrol.Pembelajaran di kelas eksperimen dan kontrol sama-sama diberikan sebanyak 6 kali dan diberikan post test untuk mengetahui kompetensi pengetahuan IPS. Metode dalam pengumpulan data yaitu metode tes, dan instrument berupa tes objektif pilihan ganda biasa. Data yang dikumpulkan adalah data kompetensi pengetahuan IPS dan dianalisis menggunakan uji t. Hasil analisis diperoleh thitung $=3,278$ dan tabel dengan $n^{1}+n^{2}-2=62$ dengan taraf signifikansi $5 \%=2,000$ karena $t_{\text {hitung }}>t_{\text {tabel }}$ berarti $\mathrm{H}_{0}$ ditolak. Nilai rata-rata kompetensi pengetahuan IPS pada kelompok eksperimen yaitu 80,34 dan rata-rata kompetensi pengetahuan IPS pada kelompok kontrol yaitu 74,13. Sehingga dapat di interprestasikan bahwa terdapat perbedaan yang siginifikan kompetensi pengetahuan IPS antara kelompok siswa yang dibelajarkan menggunakan model pembelajaran circuit learning berbantuan media flipchart dengan kelompok siswa yang dibelajarkan menggunakan pembelajaran konvensional. Maka dapat disimpulkan bahwa model pembelajaran circuit learning berbantuan media flipchart berpengaruh terhadap kompetensi pengetahuan IPS kelas V SDN Gugus I Kecamatan Kuta tahun ajaran 2018/2019.
\end{abstract}

\section{Pendahuluan}

Menurut Undang-Undang No. 20 Tahun 2003 menyatakan bahwa pendidikan adalah usaha sadar dan terencana untuk mewujudkan suasana belajar dan proses pembelajaran agar peserta didik secara aktif mengembangkan potensi dirinya untuk memiliki kekuatan spiritual keagamaan, pengendalian diri, kepribadian, kecerdasan, akhlak mulia. Dalam Pendidikan Nasional, Kurikulum merupakan seperangkat rencana dan pengaturan mengenai tujuan, isi, dan bahan pelajaran serta cara yang digunakan sebagai pedoman penyelenggaraan kegiatan pembelajaran untuk mencapai tujuan pendidikan nasional.

Tujuan pendidikan nasional adalah mencerdaskan kehidupan bangsa dan mengembangkan manusia Indonesia seutuhnya, yaitu manusia yang beriman dan bertaqwa terhadap Tuhan Yang Maha Esa dan berbudi pekerti luhur, memiliki pengetahuan dan keterampilan, kesehatan jasmani dan rohani, kepribadian yang mantap dan mandiri serta rasa tanggung jawab kemasyarakatan dan kebangsaan. Agar tujuan pendidikan nasional dapat terwujud maka diperlukan kurikulum yang sesuai dengan karakteristik siswa. 
Kurikulum yang berlaku di Indonesia pada saat ini adalah kurikulum 2013. Kurikulum 2013 merupakan penyempurnaan dari Kurikulum Tingkat Satuan Pendidikan (KTSP). Pelaksanaan kegiatan pembelajaran pada kurikulum 2013 berorientasi pada pendekatan saintifik yang dikemas dalam suatu tema. Menurut Rusman (2015:232) "pendekatan saintifik adalah sebuah pendekatan pembelajran yang menekankan pada aktifitas siswa melalui kegiatan mengamati, menanya, menalar, mencoba dan membuat jejaring pada kegiatan pembelajaran di sekolah". Pendekatan saintifik merupakan pendekatan pembelajaran yang memberikan kesempatan kepada siswa secara luas untuk melakukan eksplorasi dan elaborasi materi yang dipelajari, disamping itu memberikan kesempatan kepada peserta didik untuk mengaktualisasikan kemampuannya melalui kegiatan pembelajaran yang telah dirancang oleh guru.

Tujuan pembelajaran dengan pendekatan santifik menurut Daryanto (2014:53) didasarkan pada keunggulan pendekatan tersebut. Beberapa tujuan pembelajaran dengan pendekatan saintifik adalah: 1) Untuk meningkatkan kemampuan intelek, khususnya kemampuan bepikir tinggi siswa. 2) Untuk membentuk kemampuan siswa dalam menyelesaikan suatu masalah secara sistematik. 3) Terciptanya kondisi pembelajaran dimana siswa merasa bahwa belajar itu merupakan suatu kebutuhan. 4) Diperolehnya hasil belajar yang tinggi. 5) Untuk melatih siswa dalam mengkomunikasikan ide-ide, khususnya dalam menulis artikel ilmiah. 6) Untuk mengembangkan karakter siswa.

Guru memiliki peranan penting dalam kegiatan pembelajaran. Guru seharusnya mampu beradaptasi di era global dengan perkembangan keilmuan yang hari demi hari semakin canggih. Selain itu, guru juga harus mampu menerapkan model pembelajaran yang berdasarkan tuntutan zaman dan kebutuhan peserta didik. Tetapi, dalam proses pembelajaran berkaitan dengan muatan materi IPS terutama kompetensi pengetahuan, karena pembelajaran hanya berpusat pada guru sehingga membuat siswa kurang tertarik terhadap pembelajaran. Secara tidak langsung pola pembelajaran seperti itu akan membuat hasil belajar siswa menjadi tidak optimal.

Proses pembelajaran yang dilakukan di sekolah tidak terlepas dari komponen-komponen pembelajaran yang mencakup : tujuan, materi ajar, pendekatan, metode, media, sumber belajar dan evaluasi pembelajaran. Proses pembelajaran disekolah idealnya membutuhkan kerjasama antar komponen pembelajaran agar tercapainya tujuan dalam mata pelajaran.

Pendidikan di SD membelajarkan berbagai mata pelajaran kepada siswanya. Salah satunya adalah mata pelajaran IPS. Ilmu Pengetahuan Sosial (IPS) merupakan kajian yang memusatkan pada aktivitas kehidupan manusia. IPS mengkaji seperangkat peristiwa, fakta, konsep, dan generalisasi yang berkaitan dengan isu sosial. Melalui mata pelajaran IPS, peserta didik diarahkan untuk dapat menjadi warga Negara Indonesia yang demokratis, dan bertanggung jawab, serta warga dunia yang cinta damai. Mata pelajaran IPS disusun secara sistematis, komprehensif, dan terpadu dalam proses pembelajaran menuju kedewasaan dan keberhasilan dalam kehidupan di masyarakat. Dengan pendekatan tersebut diharapkan peserta didik akan memperoleh pemahaman yang lebih luas dan mendalam pada bidang ilmu yang berkaitan. (Badan Standar Nasional Pendidikan tahun 2006).

Tujuan pembelajaran IPS di SD menurut Gunawan (2013:48), bahwa bertujuan untuk: (1) Membekali anak didik dengan pengetahuan sosial yang berguna dalam kehidupannya di masyarakat (2) Membekali anak didik dengan kemampuan mengidentifikasi, menganalisis dan menyusun alternative pemecahan masalah sosial yang terjadi dalam kehidupan di masyarakat. (3) Membekali anak didik dengan kemampuan berkomunikasi dengan sesama warga masyarakat dan berbagai bidang keilmuan serta bidang keahlian. (4) Membekali anak didik dengan kesadaran, sikap mental yang positif dan keterampilan terhadap pemanfaatan lingkungan hidup yang menjadi bagian dari kehidupan tersebut. (5) Membekali anak didik dengan kemampuan mengembangkan pengetahuan dan keilmuan IPS sesuai dengan perkembangan kehidupan, masyarakat, ilmu pengetahuan dan teknologi. 
Berdasarkan observasi pada tanggal 13 November 2018, pembelajaran dengan muatan materi IPS di SDN Gugus 1 Kecamatan Kuta masih berpusat pada guru, siswa kurang aktif dalam pembelajaran sehingga pelajaran menjadi membosankan. Cara yang bisa dilakukan agar pembelajaran tidak membosankan adalah dengan menggunakan model pembelajaran. "Model pembelajaran adalah suatu perencanaan atau suatu pola yang digunakan sebagai pedoman dalam merencanakan pembelajaran di kelas" (Ngalimun,2012:27). Salah satu alternative model pembelajaran yang bisa digunakan adalah Model pembelajaran Circuit Learning. Menurut Huda (2013:311) Model pembelajaran circuit learning adalah model pembelajaran yang memaksimalkan pemberdayaan pikiran dan perasaan dengan pola penambahan (adding) dan pengulangan (repetition). Model ini biasanya dimulai dari tanya jawab tentang topik yang dipelajari, penyajian peta konsep, penjelasan mengenai peta konsep, pembagian ke dalam beberapa kelompok, pengisian lembar kerja siswa disertai dengan peta konsep, penjelasan tentang tata cara pengisian, pelaksanaan presentasi kelompok, dan pemberian reward atau pujian. Kelebihan dari Model Pembelajaran Circuit Learning menurut Shoimin (2014:35): 1) Kreatifitas siswa dalam merangkai kata dengan bahasa sendiri lebih terasah. 2) Konsentrasi yang terjadi membuat siswa fokus dalam belajar.

Langkah-langkah model pembelajaran circuit learning adalah (1) Guru meminta siswa membaca materi untuk membuat catatan kreatif, (2) Guru bertanya kepada siswa mengenai materi pembelajaran yang ditampilkan guru menggunakan media flipchart, (3) Guru memberikan lembar kerja dan meminta setiap kelompok untuk mengerjakannya, (4) Siswa mempresentasikan hasil diksusinya di depan kelas, (5) Guru memberikan penguatan berupa pujian atau hadiah atas hasil presentasi yang bagus serta memberikan semangat kepada mereka yang belum dapat pujian atau hadiah untuk berusaha lebih giat lagi.

Model pembelajaran ini bisa menjadi alternative model pembelajaran karena melibatkan keaktifan siswa. Pembelajaran di kelas akan lebih mudah dipahami oleh siswa dengan kehadiran media pembelajaran. "Media pembelajaran adalah sarana pendidikan yang dapat digunakan sebagai perantara dalam proses pembelajaran untuk mempertinggi efektivitas dan efisiensi dalam mencapai tujuan pengajaran" (Sanaky,2009:4). Tujuan media pembelajaran sebagai alat bantu dalam proses pembelajaran adalah sebagai berikut: a.) mempermudah proses pembelajaran di kelas, b.) meningkatkan efisiensi proses pembelajaran, c.) menjaga relevansi antara materi pelajaran dengan tujuan belajar, dan d.) membantu konsentrasi pembelajar dalam proses pembelajaran.

Manfaat media pembelajaran sebagai alat bantu dalam proses pembelajaran adalah sebagai berikut: 1) Pengajaran lebih menarik perhatian peserta didik sehingga dapat menumbuhkan motivasi belajar, 2) Bahan pengajaran akan lebih jelas maknanya, sehingga dapat lebih dipahami peserta didik, serta memungkinkan pembelajar menguasai tujuan pengajaran dengan baik, 3) Metode pembelajaran bervariasi, tidak semata-mata hanya komunikasi verbal melalui penuturan kata-kata lisan pengajar, peserta didik tidak bosan dan pengajar tidak kehabisan tenaga, 4) Peserta didik lebih banyak melakukan kegiatan belajar, sebab tidak hanya mendengarkan penjelasan dari pengajar saja, tetapi juga aktivitas lain yang dilakukan seperti: mengamati, melakukan, mendemonstrasikan, dan lain-lain.

Salah satu media inovatif yang dapat digunakan adalah Media flipchart. "Media flipchart adalah lembaran-lembaran kertas yang membentuk album atau kalender yang berukuran 50x75 $\mathrm{cm}$, atau ukuran yang lebih kecil $21 \times 28 \mathrm{~cm}$ sebagai flipbook yang disusun dalam urutan yang diikat pada bagian atasnya" (Susilana dan Riyana,2009:87). Maka pembelajaran seperti ini diharapkan dapat berpengaruh pada kompetensi pengetahuan IPS siswa. Tujuan media pembelajaran sebagai alat bantu dalam proses pembelajaran adalah sebagai berikut: a.) mempermudah proses pembelajaran di kelas, b.) meningkatkan efisiensi proses pembelajaran, c.) menjaga relevansi antara materi pelajaran dengan tujuan belajar, dan d.) membantu konsentrasi pembelajar dalam proses pembelajaran. Sebagai salah satu media pembelajaran, flipchart memiliki beberapa kelebihan, diantaranya: 1) Mampu menyajikan pesan pembelajaran secara ringkas dan praktis, 2) dapat digunakan di dalam ruangan atau luar ruangan, 3) Bahan 
pembuatan relatif murah, 4) Mudah dibawa kemana-mana (moveable), dan 5) Meningkatkan aktivitas belajar siswa.

Berdasarkan uraian di atas, agar pembelajaran IPS menjadi lebih aktif dan tidak membosankan maka peneliti tertarik untuk menggunakan model Circuit learning berbantuan media flipchart dalam pembelajaran dengan muatan materi IPS dengan melaksanakan penelitian yang berjudul "Pengaruh Model pembelajaran Circuit Learning Berbantuan Media Flipchart terhadap Kompetensi Pengetahuan IPS Siswa Kelas V SDN di Gugus I Kecamatan Kuta Tahun Ajaran 2018/2019".

\section{Metode}

Penelitian ini termasuk penelitian eksperimen semu karena tidak semua variabel yang relevan dapat dikontrol atau dimanipulasi, kecuali beberapa variabel yang diteliti. Penelitian ini mengikuti desain penelitian eksperimen semu (quasi eksperimen) dengan rancangan nonequivalent post test only control grup design, yang secara prosedural mengikuti pola yang ditunjukan oleh gambar dibawah ini:

\begin{tabular}{lll}
\hline Kelas & Perlakuan & Post-test \\
\hline Eksperimen & $\mathrm{X}_{1}$ & $\mathrm{O}_{1}$ \\
\hline Kontrol & $\mathrm{X}_{2}$ & $\mathrm{O}_{2}$ \\
\hline \multicolumn{3}{c}{ Gambar 1 } \\
\multicolumn{3}{c}{ Rancangan Non-equivalent Post test only control grup design }
\end{tabular}

(Sumber : Agung,2014:163)

Keterangan :

$\mathrm{X}_{1} \quad$ : Perlakuan pada kelompok eksperimen.

$\mathrm{X}_{2} \quad$ : Dibelajarkan secara konvensional pada kelompok kontrol.

$\mathrm{O}_{1} \quad$ : Menyatakan pengamatan akhir (post-test) pada kelompok eksperimen.

$\mathrm{O}_{2} \quad$ : Menyatakan pengamatan akhir (post-test) pada kelompok kontrol.

Pada desain ini kelompok eksperimen diberikan pembelajaran dengan menerapkan model pembelajaran Circuit learning, sedangkan untuk kelompok kontrol pembelajaran secara konvensional. Dalam penelitian ini penyetaraan menggunakan nilai ulangan harian IPS, setelah itu untuk nilai Post test dianalisis sebagai data penelitian.

Populasi dalam penelitian ini adalah seluruh siswa kelas V SDN Gugus I Kecamatan Kuta, yang terdiri dari 9 kelas. Jumlah populasi dari penelitian ini adalah 343 siswa.

Teknik pengambilan sampel pada penelitian ini adalah Random Sampling. Dimana pada saat pengambilan sampel yang di random adalah kelasnya, sehingga semua kelas mendapatkan peluang yang sama untuk menjadi sampel penelitian.

Pengambilan sampel dilakukan dengan cara undian. Dalam penelitian ini, setiap kelas memiliki hak yang sama dan mendapatkan kesempatan dipilih menjadi sampel yang dilakukan dengan cara dua kali pengundian. Cara yang digunakan dengan cara menulis nomor pada semua kelas V di seluruh SD Negeri populasi pada masing-masing kertas yang jumlahnya 9 kelas, kemudian kertas digulung. Lalu gulungan kertas dimasukkan ke dalam dalam kotak lalu dikocok. Tahap pertama pengundian untuk memilih dua kelas yang akan dijadikan sampel penelitian.

Setelah itu, dilakukan uji prasyarat untuk memenuhi syarat melakukan uji kesetaraan menggunakan uji-t. Setelah sampel setara, pengundian kedua dilakukan untuk memilih kelas yang akan dijadikan kelas eksperimen dan kelas kontrol.

Data yang dikumpulkan dalam penelitian ini adalah data tentang kompetensi pengetahuan IPS siswa kelas V SDN Gugus I Kecamatan Kuta, Tahun Ajaran 2018/2019. Metode yang digunakan dalam penelitian ini adalah metode tes. Tes kompetensi pengetahuan ini dibuat Rafflesines Yuanisa Romaliyana, Made Putra, I Wayan sujana. (2019). 
berupa tes objektif dalam bentuk pilihan ganda biasa. Dalam penelitian ini menggunakan tes pilihan ganda biasa yang sudah tervalidasi.

Metode analisis data yang digunakan dalam penelitian ini yaitu analisis statistic inferensial. Karena untuk mencari perbedaan, maka analisis inferensial yang digunakan dalam penelitian ini adalan uji-t ( $t$-test). Untuk dapat menggunakan teknik analisis tersebut dibutuhkan data yang berdistribusi normal dan homogen. Maka perlu dilakukan uji normalitas data dan uji homogenitas untuk memenuhi prasyarat yang dibutuhkan untuk menggunakan teknik analisis $\mathrm{Uji}-\mathrm{t}(\mathrm{t}$-test).

\section{Hasil}

\section{Hasil dan Pembahasan}

Deskripsi data hasil penelitian ini memaparkan mengenai perolehan hasil post test pada kelompok eksperimen dan kelompok kontrol di SDN Gugus I Kecamatan Kuta Tahun Ajaran 2018/2019. Data yang diperoleh dalam penelitian ini dikelompokkan menjadi dua yaitu data kompetensi pengetahuan IPS siswa kelompok eksperimen di SD No. 3 Kuta dan data kompetensi pengetahuan IPS di SD No. 4 Kuta.

Dari data tes kompetensi pengetahuan IPS dengan 30 butir soal yang dilakukan setelah 6 kali perlakuan, tes diberikan pada tanggal 17 Mei 2019. Banyaknya siswa pada kelompok eksperimen adalah 32 dan kelompok kontrol adalah 32 siswa. Data nilai rata-rata (M), Varian (S) dan standar deviasi (SD) disajikan dalam tabel 1.

Tabel 1. Tabel Nilai Rata-Rata, Varian, dan Standar Deviasi Kompetensi Pengetahuan IPS Siswa Kelas V di SDN Gugus 1 Kecamatan Kuta

\begin{tabular}{lcccc}
\hline $\begin{array}{l}\text { Model } \\
\text { Pembelajaran }\end{array}$ & $\begin{array}{c}\text { Jumlah siswa tiap } \\
\text { kelompok }\end{array}$ & Nilai Rata-rata & Varian & Standar Deviasi \\
\hline $\begin{array}{l}\text { Kelompok } \\
\text { Eksperimen }\end{array}$ & 32 & 80,34 & 64,81 & 8,05 \\
\hline $\begin{array}{l}\text { Kelompok } \\
\text { Kontrol }\end{array}$ & 32 & 74,13 & 54,82 & 7,40 \\
\hline
\end{tabular}

Berdasarkan tabel 1 Nilai rata-rata kompetensi pengetahuan IPS kelompok siswa yang dibelajarkan melalui model pembelajaran circuit learning Berbantuan media flipchart untuk kelompok eksperimen adalah $\bar{X}=80,34$ dengan varian sebesar $\mathrm{S}^{2}=64,81$ dan standar deviasi $\mathrm{S}=$ 8,05 . Sedangkan nilai rata-rata kompetensi pengetahuan IPS kelompok siswa yang dibelajarkan secara konvensional untuk kelompok kontrol adalah $\bar{X}=74,13$ dengan varian $\mathrm{S}^{2}=54,82$ dan standar deviasi $\mathrm{S}=7,40$.

Uji normalitas dilakukan untuk menguji apakah suatu distribusi empirik mengikuti ciriciri distribusi normal atau untuk menyelidiki bahwa $\mathrm{f}_{0}$ (frekuensi observasi) dari gejala yang diselidiki tidak menyimpang secara signifikan dari $\mathrm{f}_{\mathrm{h}}$ (frekuensi harapan) dalam distribusi normal teoritik dengan ketentuan $\mathrm{h}_{0}: \mathrm{f}_{0}=\mathrm{f}_{\mathrm{h}}$ dan $\mathrm{H}_{\mathrm{i}}: \mathrm{f}_{0} \neq \mathrm{f}_{\mathrm{h}}$. Uji Normalitas data dilakukan terhadap kompetensi pengetahuan IPS siswa baik kelompok eksperimen maupun kelompok kontrol disajikan dalam tabel 2.

Tabel 2. Tabel Rekapitulasi Hasil Uji Normalitas Sebaran Data Kelompok Eksperimen dan Kelompok Kontrol

\begin{tabular}{ccccc}
\hline No. & $\begin{array}{c}\text { Kelompok Data } \\
\text { Kompetensi } \\
\text { Pengetahuan IPS }\end{array}$ & $\mathbf{X}_{\mathbf{0}^{2}}$ & $\begin{array}{c}\text { Nilai Kritis dengan Taraf signifikan } \\
\mathbf{5 \%}\end{array}$ & Status \\
\hline 1 & Eksperimen & 6,39 & 11,07 & Normal \\
\hline 2 & Kontrol & 1,69 & 11,07 & Normal \\
\hline
\end{tabular}


Adapun kaidah pengujian adalah jika $\mathrm{X}_{h}{ }^{2}<\mathrm{X}^{2}$ tabel maka data berdistribusi normal, sedangkan jika $\mathrm{X}_{h}^{2}>\mathrm{X}^{2}$ tabel maka data tidak berdistribusi normal.

Dari hasil perhitungan dengan menggunakan rumus chi kuadrat, kompetensi pengetahuan IPS kelompok eksperimen $\mathrm{X}_{h^{2}}=6,39$ pada taraf signifikan $5 \%$ dan $\mathrm{dk}=5$ (6-1) dan diketahui $\mathrm{X}_{\text {tabel }}=11,07$, ini berarti bahwa $\mathrm{X}_{h}^{2}=6,39<\mathrm{X}^{2}$ tabel $=11,07$ maka data kompetensi pengetahuan IPS pada kelompok eksperimen berdistribusi normal. Sedangkan chi kuadrat data kompetensi pengetahuan IPS kelompok Kontrol $\mathrm{X}_{h}{ }^{2}=1,69$ pada taraf signifikan $5 \%$ dan $\mathrm{dk}=5$ (6-1) dan diketahui $\mathrm{X}^{2}$ tabel $=11,07$, ini berarti bahwa $\mathrm{X}_{h}{ }^{2}=1,69<\mathrm{X}_{\text {tabel }}=11,07$ maka data kompetensi pengetahuan IPS pada kelompok kontrol juga berdistribusi normal. Berdasarkan data kompetensi pengetahuan IPS terbukti baik kelompok eksperimen maupun kelompok kontrol berdistribusi normal.

Uji homogenitas varians dilakukan terhadap variansi pasangan antar kelompok. $\mathrm{H}_{0}: \mathrm{S}_{1}{ }^{2}=$ $\mathrm{S}_{2}{ }^{2}$ dan $\mathrm{H}_{\mathrm{i}}: \mathrm{S}_{1}{ }^{2} \neq \mathrm{S}_{2}{ }^{2}$. Rumus yang digunakan adalah uji-F dengan kriteria data homogen jika $\mathrm{F}_{0}<$ $\mathrm{F}_{\text {tabel }}$. Dengan db penyebut $=31$ db pembilang $=31$ dan taraf signifikan $5 \%$ diketahui $\mathrm{F}_{\text {tabel }}=$ 1,82. Ini berati $F_{\text {hitung }}=1,18<\mathrm{F}_{\text {tabel }}=1,82$ maka data kompetensi pengetahuan IPS kelompok eksperimen dan data kompetensi pengetahuan IPS kelompok kontrol homogen.

Hasil uji prasyarat yaitu uji normalitas dan homogenitas diperoleh bahwa data dari kelompok eksperimen dan kelompok kontrol berdistribusi normal dan homogen. Berdasarkan hal tersebut, maka dilanjutkan pada pengujian hipotesis penelitian $\left(\mathrm{H}_{\mathrm{a}}\right)$ yang telah diajukan pada kajian teori. Sebelum dilakukan uji hipotesis, hipotesis yang ada di Bab II diubah terlebih dulu menjadi hipotesis $\left(\mathrm{H}_{0}\right)$. Sehingga hasil analisis akan membuktikan apakah data yang diperoleh

Dari hasil pengukuran terhadap responden akan mendukung atau tidak terhadap hipotesis yang telah diajukan. Adapun hipotesis nol $\left(\mathrm{H}_{0}\right)$ yang akan di uji menyatakan bahwa tidak terdapat pengaruh yang signifikan model pembelajaran circuit learning berbantuan media flipchart terhadap kompetensi pengetahuan IPS siswa kelas V SDN Gugus 1 Kecamatan Kuta.

$$
\begin{array}{ll}
\mathrm{H}_{0}=\mu_{1}=\mu_{2} \text { atau } \mathrm{H}_{0}=\mathrm{S}_{1}{ }^{2}=\mathrm{S}_{2}{ }^{2} \\
\mathrm{H}_{0}=\mu_{1} \neq \mu_{2} \text { atau } \mathrm{H}_{0}=\mathrm{S}_{1}{ }^{2} \neq \mathrm{S}_{2}{ }^{2}
\end{array}
$$

Pengujian hipotesis tersebut melalui uji-t dengan kaidah hipotesis, $\mathrm{H}_{0}$ ditolak jika $t_{\text {hitung }}>t_{\text {tabel }}$ dan $\mathrm{H}_{0}$ diterima jika $t_{\text {hitung }}<t_{\text {tabel. }}$. Hasil analisis uji hipotesis disajikan sebagai berikut disajikan dalam tabel 3.

Tabel 3. Tabel Uji Homogenitas Varians antar Kelompok Eksperimen dengan Kelompok Kontrol.

\begin{tabular}{cccc}
\hline Kelompok Penelitian & $\mathbf{F}_{\mathbf{0}}$ & $\begin{array}{c}\text { Nilai Ftabel dengan Taraf } \\
\text { signifikan 5\% }\end{array}$ & Status \\
\hline $\begin{array}{c}\text { Kompetensi } \\
\begin{array}{c}\text { Pengetahuan IPS } \\
\text { kelompok kontrol dan } \\
\text { eksperimen }\end{array}\end{array}$ & 1,18 & 1,82 & Homogen \\
\hline
\end{tabular}

Hasil perhitungan uji-t, diperoleh $t_{\text {hitung }}=3,278$ untuk mengetahui signifikansinya, dikonsultasikan dengan nilai $t_{\text {tabel. }}$. Dengan $d k=64(\Sigma n-2=64-2=62)$ dan taraf signifikansi adalah 5\% diperoleh $t_{\text {tabel }}=2,000$, karena $t_{\text {hitung }}=3,278>t_{\text {tabel }}=2,000$, maka hipotesis nol $\left(\mathrm{H}_{0}\right)$ ditolak dan (Ha) diterima, ini artinya terdapat pengaruh yang signifikan model pembelajaran circuit learning berbantuan media flipchart terhadap kompetensi pengetahuan IPS Siswa Kelas V SDN Gugus I Kecamatan Kuta Tahun Ajaran 2018/2019.

\section{Pembahasan}

Rafflesines Yuanisa Romaliyana, Made Putra, I Wayan sujana. (2019).

Pengaruh Model Pembelajaran Circuit Learning Berbantuan Media Flipchart Terhadap Kompetensi Pengetahuan IPS Siswa Kelas V. 
Pada bagian ini akan dibahas lebih lanjut mengenai hasil penelitian yang diperoleh dari kelompok eksperimen dan kelompok kontrol. Data kompetensi pengetahuan IPS diperoleh ratarata pada kelompok eksperimen yaitu $\bar{x}=80,34$ dan pada kelompok kontrol $\bar{x}=74,13$. Dari hasil analisis diketahui bahwa sebaran data kompetensi pengetahuan IPS siswa berdistribusi normal dan memiliki varians yang homogen. Dari hasil analisis diperoleh $t_{\text {hitung }}=3,278$ dan $t_{\text {tabel }}$ $=2,000$ pada taraf signifikansi $5 \%$ dengan $\mathrm{dk}=\mathrm{n} 1+\mathrm{n} 2-2=(32+32-2)=62$. Oleh karena $\mathrm{t}_{\text {hitung }}$ $3,278>t_{\text {tabel }} 2,000$ maka $\mathrm{H}_{0}$ yang menyatakan tidak terdapat pengaruh yang signifikan model pembelajaran Circuit Learning berbantuan media flipchart terhadap kompetensi pengetahuan IPS siswa kelas V SDN Gugus I Kecamatan Kuta Tahun Ajaran 2018/2019 di tolak dan $\mathrm{H}_{\mathrm{a}}$ yang menyatakan bahwa terdapat pengaruh yang signifikan model pembelajaran Circuit Learning berbantuan media flipchart terhadap kompetensi pengetahuan IPS siswa kelas V SDN Gugus I Kecamatan Kuta Tahun Ajaran 2018/2019 diterima.

Setelah menganalisis data post test diperoleh rata-rata kompetensi pengetahuan IPS pada kedua kelompok, nilai rata-rata kompetensi pengetahuan IPS pada kelompok eksperimen yaitu 80,34 dan kelompok kontrol yaitu 74,13. Hal ini menunjukkan bahwa nilai rata-rata kompetensi pengetahuan IPS kelompok eksperimen lebih tinggi dibandingkan dengan nilai rata-rata kompetensi pengetahuan IPS kelompok kontrol.

Hal ini disebabkan oleh adanya perbedaan perlakuan pada langkah-langkah pembelajaran. Shoimin (2014:33) Menyatakan bahwa Circuit Learning adalah memaksimalkan dan mengupayakan pemberdayaan pikiran dan perasaan dengan pola bertambah dan mengulang. Langkah-langkah model pembelajaran circuit learning adalah (1) Guru meminta siswa membaca materi untuk membuat catatan kreatif, (2) Guru bertanya kepada siswa mengenai materi pembelajaran yang ditampilkan guru menggunakan media flipchart, (3) Guru memberikan lembar kerja dan meminta setiap kelompok untuk mengerjakannya, (4) Siswa mempresentasikan hasil diksusinya di depan kelas, (5) Guru memberikan penguatan berupa pujian atau hadiah atas hasil presentasi yang bagus serta memberikan semangat kepada mereka yang belum dapat pujian atau hadiah untuk berusaha lebih giat lagi.

Model pembelajaran Circuit Learning berbantuan media flipchart akan membuat siswa lebih bersemangat dalam proses pembelajaran karena dapat melatih kreatifitas siswa merangkai kata dengan bahasa sendiri dan membuat siswa lebih konsentrasi membuat siswa fokus dalam pembelajaran, sehingga pembelajaran akan menjadi lebih menyenangkan karena siswa dirangsang untuk aktif dalam pembelajaran. Sedangkan pada kelompok kontrol yang tidak menggunakan model pembelajaran Circuit Learning berbantuan media flipchart, media yang digunakan hanya sebatas seperti buku pegangan dan media yang seadanya yang ada di kelas. Hal tersebut juga bisa membuat siswa merasa kurang bersemangat dalam belajar karena pembelajaran masih banyak ceramah dan pembelajaran bersifat satu arah.

Hasil penelitian ini memperkuat simpulan yang disampaikan oleh Dewi (2014) menyatakan, hasil penelitian menunjukkan bahwa terdapat pengaruh yang signifikan Model Pembelajaran Circuit Learning terhadap kompetensi pengetahuan IPS Kelas V SD. Selanjutnya penelitian dari Hakim (2015) yang menunjukkan bahwa keterlaksanaan pembelajaran dengan model Circuit Learning mencapai 100\%. Hasil tersebut diperoleh karena siswa diberi kesempatan untuk menguatkan ingatannya dan menuliskannya dalam bentuk peta pikiran yang telah ditambah dengan catatan kecil. Tidak hanya menyusun peta konsep, siswa juga diberi kesempatan untuk mengulang atau mempelajari kembali peta konsepnya untuk menguji daya ingat mereka. Dengan membuat peta konsep, siswa memusatkan perhatiannya secara penuh untuk menyelesaikan peta konsep tersebut. Ditambah lagi dengan pengulangan dan penambahan informasi ke dalam peta konsep yang dibuat, konsentrasi siswa akan tercurahkan dan pengetahuan akan mudah meresap ke dalam ingatan siswa.

Berdasarkan pemaparan tersebut, dapat disimpulkan bahwa model pembelajaran Circuit Learning berbantuan media flipchart berpengaruh terhadap kompetensi pengetahuan IPS siswa kelas V SDN Gugus I Kecamatan Kuta Tahun Pelajaran 2018/2019. 


\section{Simpulan}

Berdasarkan hasil penelitian dan pembahasan, dapat disimpulkan sebagai berikut.

Terdapat pengaruh yang signifikan kelompok siswa yang dibelajarkan menggunakan model pembelajaran Circuit Learning berbantuan media flipchart terhadap Kompetensi Pengetahuan IPS siswa kelas V di SDN Gugus I Kecamatan Kuta Tahun Ajaran 2018/2019. Ini diperkuat oleh hasil uji hipotesis menggunakan uji-t. Berdasarkan hasil analisis dengan menggunakan uji-t dengan $\mathrm{dk}=\mathrm{n} 1+\mathrm{n} 2-2=62$ pada taraf signifikansi $5 \%$ diperoleh $\mathrm{t}_{\text {hitung }}=$ $3,278>t_{\text {tabel }}=2,000$ sehingga Ho ditolak. Nilai rata-rata kompetensi pengetahuan IPS kelompok eksperimen $=80,34$ sedangkan nilai rata-rata kompetensi pengetahuan IPS kelompok kontrol $=$ 74,13. Sehingga nilai rata-rata kompetensi pengetahuan IPS kelompok eksperimen lebih tinggi dibandingkan kompetensi pengetahuan IPS kelompok kontrol yaitu 80,34> 74,13.

Ada beberapa saran yang dapat diajukan berdasarkan temuam dan kajian penelitian ini adalah sebaga berikut.

1. Kepada Guru

Berdasarkan temuan penelitian yang diperoleh, disarankan kepada guru agar lebih kreatif untuk memberikan fasilitas berupa sumber belajar dan kesempatan yang lebih besar bagi siswa pada pembelajaran dengan menggunakan model pembelajaran Circuit Learning berbantuan media flipchart sehingga tercipta pembelajaran yang lebih aktif dan menyenangkan bagi siswa.

2. Kepada Kepala Sekolah

Berdasarkan temuan penelitian, lembaga sekolah disarankan agar dapat menggunakan hasil penelitian ini sebagai pendukung sumber belajar guru dalam meningkatkan kualitas pembelajaran di sekolah sehingga sekolah mampu menghasilkan siswa yang memiliki output berkualitas.

3. Kepada Peneliti Lain

Berdasarkan temuan penelitian, disarankan kepada peneliti agar hasil penelitian ini digunakan sebagai referensi untuk melaksanakan penelitian selanjutnya atau menemukan inovasi kegiatan pembelajaran lainnya yang bermakna dan menyenangkan bagi siswa.

\section{Ucapan Terima Kasih}

Sebagai rasa syukur pada kesempatan ini saya ucapkan terimakasih kepada Universitas Pendidikan Genesha yang telah berkontribusi memberikan arahan dan acuan terhadap penyusunan artikel ini. Saya mengucapkan terimakasih kepada kedua orang tua saya yang telah memberikan dukungan dana maupun moral kepada saya,ibu dan bapak adalah orang tua yang paling hebat bagi saya. Kepada kakak dan adik saya yang telah banyak menghibur saya dan menjadi tempat berkeluh-kesah dalam pengerjaan skirpsi maupun artikel ini. Teruntuk kekasih saya yang senantiasa menjadi tempat saya berkeluh-kesah,namun kamu selalu memberikan semangat dan terimakasih atas segala perhatian yang telah diberikan. Untuk teman-teman kelas I yang senantiasa membantu dan memberikan dukungan kepada saya. Tidak mengurangi rasa hormat saya mengucapkan banyak terimakasih untuk kedua pembimbing saya yaitu Bapak Drs. Made Putra dan Bapak Drs. I Wayan Sujana yang telah membimbing saya dengan sabar. Tak lupa saya mengucapkan terimakasih kepada Bapak dan Ibu Guru di SDN Gugus I Kecamatan Kuta yang telah memberikan saya kesempatan untuk melakukan penelitian di Gugus I Kecamatan Kuta. Terima kasih kepada anak-anak di SD No.3 Kuta dan SD No.4 Kuta yang telah berpatisipasi dalam penelitian saya.

\footnotetext{
* Corresponding author.

E-mail Addresses: rafflesines.yuanisa.romaliyana@undiksha.ac.id1, madeputra@undiksha.ac.id2, iwayan.sujana@undiksha.ac.id3 


\section{Daftar Pustaka}

Agung, A.A. Gede. 2014. Metodologi Penelitian Pendidikan. Malang: Aditya Media Publising

Arikunto, Suharsimi. 2018. Dasar-dasar Evaluasi Pendikan. Jakarta : Bumi Aksara

Aris Shoimin. 2013. 68 Model Pembelajaran Inovatif dalam Kurikulum 2013.Yogyakarta : AR-Ruzz Media

Badan Standar Nasional Pendidikan, 2006. Kurikulum Tingkat Satuan Pendidikan (KTSP). Jakarta: Departemen Pendidikan Nasional

Daryanto. 2014. Pembelajaran Tematik, Terpadu, Terintegrasi (Kurikulum 2013). Yogyakarta: Gava Media.

Dewi, Dewa Ayu Puspa, dkk. 2014. "Pengaruh Model Pembelajaran Circuit Learning Berbantuan Media Audiovisual Terhadap Hasil Belajar IPS Siswa SD Negeri 1 Pejeng Tahun Pelajaran 2013/2014". Jurnal Mimbar PGSD Universitas Pendidikan Ganesha, Volume 2.

Gunawan, Rudy. 2013. Pendidikan IPS Filosofi, Konsep, dan Aplikasi. Bandung: Alfabeta.

Hakim, Arif Rochman. 2015. "Pengaruh Model Circuit Learning Terhadap Hasil Belajar Siswa Tema Ekosistem di Sekolah Dasar”. JPGSD, Volume Nomor2.

Huda, Miftahul. 2013. Model-model Pengajaran dan Pembelajaran Isu-isu Metodis dan Paradigmatis. Yogyakarta: Pustaka Pelajar.

Ngalimun. 2012. Strategi dan model pembelajaran. Banjarmasin: Aswaja Pressindo.

Rusman. 2015. Pembelajaran Tematik Terpadu: Teori, Praktik, dan Penilaian. Bandung: PT Raja Grafindo Persada.

Sanaky, Hujair. 2009. Media Pembelajaran. Yogyakarta: Safiria Insania Press. 